ZOOLOGIA 28 (6): 777-783, December, 2011

doi: $10.1590 /$ S1984-46702011000600011

\title{
Quantitative study of Trichodina heterodentata (Ciliophora: Mobilia) infrapopulations infesting tadpoles of a Brazilian endemic toad Rhinella pombali (Anura: Bufonidae)
}

\author{
Noemi M. Fernandes ${ }^{1,3}$; Bianca Sartini ${ }^{2}$; Roberto J. P. Dias' \& Marta D’Agosto² \\ ' Laboratório de Protistologia, Departamento de Zoologia, Centro de Ciências da Saúde, Universidade Federal do Rio de \\ Janeiro. Avenida Carlos Chagas Filho 373, Ilha do Fundão, Rio de Janeiro, Brazil. \\ ${ }^{2}$ Laboratório de Protozoologia, Instituto de Ciências Biológicas, Universidade Federal de Juiz de Fora. \\ ${ }^{3}$ Corresponding author. E-mail: noemi.fernandes@yahoo.com.br
}

\begin{abstract}
In this work we investigated the quantitative aspects of the relationship between Rhinella pombali (Baldissera, Caramaschi \& Haddad, 2004) tadpoles and their trichodinid ectoparasites. Specimens were collected from a small stream located at an agricultural area between rainforest fragments in southeastern Brazil. A total of 80 tadpoles were investigated. Trichodina heterodentata Duncan, 1977 was the only trichodinid ciliate species recovered. All tadpoles were naturally infested by $T$. heterodentata with a mean intensity of $695.14 \pm 33.33$ trichodinid ciliates per tadpole. A positive correlation was observed between the intensity of the infestation and tadpole weight. Intensity of infestation did not significantly influence mean trichodinid diameter in the populations studied. This is the first study investigating density-dependent effects in interspecific interactions between trichodinids and anurans.
\end{abstract}

KEY WORDS. Anurans; conservation; ectoparasites; parasitism; trichodinids.

Rhinella pombali (Baldissera, Caramaschi \& Haddad, 2004) is an endemic toad from the Brazilian rainforest, specifically found in transition areas of tropical savannah habitat in the states of Minas Gerais (BALDISSERA et al. 2004) and Rio de Janeiro (Silveira et al. 2009). Rainforests are critical areas for conservation because their biodiversity is threatened by human impact (MYers et al. 2000). Rhinella pombali is a widespread abundant species and larvae develop in temporary pools adjacent to streams (BALDISSERA 2008).

Amphibian populations are declining or disappearing in many parts of the world; one of the causes is parasite infestation (Stuart et al. 2004). Parasitism reduces the energy available for tadpole metamorphosis, resulting in organisms with little chance of survival (PARRIS \& BAUD 2004). Amphibian defence mechanisms against ectoparasites include innate adaptive immune responses, which are less effective in the larval stage and directly influence the intensity of infestation (KaTTAR 1975, Green 2001). Host size (Özer 2007), as well as age and nutritional status (Zanolo \& Yamamura 2006) may also influence ectoparasite intensity in amphibian populations. One environmental factor, eutrophication, has a direct influence on trichodinid behaviour and infestation. Eutrophic environments alter bacterial communities and induce faster trichodinid proliferation, increasing infestation and pathogenesis levels (Zanolo \& Yamamura 2006).
Ciliate protozoa of the genus Trichodina Ehrenberg, 1838 (Ciliophora: Trichodinidae) are widely known fish ectoparasites which cause severe damage to their hosts, with consequent economic losses in many countries (Lom 1995). Besides infesting fish, trichodinids may parasitize the external surfaces or the urinary bladders of amphibians. Heavy parasite loads may be associated with clinical diseases such as skin discolouration, ulcers, and reddened gills (POYNTON \& WhitaKer 2001). There are reports of endo and ectoparasitism by trichodinids in species of amphibians such as Bufo Laurenti, 1768 (Bufonidae), Rana Linnaeus, 1758 (Ranidae) and Xenopus Wagler, 1827 (Pipidae) (Diller 1928, Lom 1958, Chen 1963, Kattar 1975, Tomava \& Golemansky 2001). In Brazil there are reports of $T$. steini Claparède \& Lachmann, 1858 on Bufo ictericus Spix, 1824 tadpoles (KatTar 1975) and T. heterodentata Duncan, 1977 on $R$. pombali tadpoles (Dias et al. 2009).

Despite the influence of parasitism on amphibian population structure (STUART et al. 2004), there are few studies on the ecology of trichodinids as frog's ectoparasites (Tomava \& Golemansky 2001, Nieto et al. 2007). In South America there have been no investigations on the subject. An increase in parasite intensity can alter parasite characteristics, for instance causing a decrease in the average size of individuals (Dezfuli et al. 2002, CHURCHER et al. 2006) due to food restriction and increased competition. These effects are known as density-dependent. 
However, density-dependent studies on ciliate ectoparasite populations are scarce.

This is the first quantitative analysis studying the prevalence, abundance, intensity of infestation, and distribution pattern of infrapopulations (all individuals of a parasite species that are on an individual host at a particular time - BusH et al. 1997) of trichodinids infesting endemic tadpoles in a Brazilian rainforest. We also investigated how those parasitological parameters are related to host weight, and whether infestation intensity influenced the mean diameter of parasites, as a density-dependence effect.

\section{MATERIAL AND METHODS}

One hundred and twenty tadpoles were collected (IBAMA license number: $447 / 06-N U F A S-M G)$ with a sieve ( $20 \mathrm{~cm}$ diameter) in a $100 \mathrm{~m}$ transect of a stream in the Sagrado Coração de Jesus Farm $\left(21^{\circ} 49^{\prime} 00.04^{\prime \prime} \mathrm{S}, 43^{\circ} 21^{\prime} 21.67^{\prime \prime} \mathrm{W}\right)$. The farm is located in the agricultural area of the city of Juiz de Fora, southeastern Brazil. Eighty of the tadpoles were immediately placed in individual plastic containers with $5 \mathrm{~mL} \mathrm{7 \%}$ formalin solution for fixation. The remaining 40 tadpoles were kept alive in containers with stream water for in vivo observation of ciliates. After analysis, the tadpoles were identified by specialists from the Department of Zoology and Botany, UNESP, São José do Rio Preto, state of São Paulo and deposited in the UNESP collection (DZSJRP - 1317.1). The key used for species identification can be found in Baldissera et al. (2004). All tadpoles collected were in stage 26 (GosNER 1960).

Each fixed tadpole, along with the formalin in the vial, was placed in a Petri dish where the body surface of the host was scraped with a scalpel. The content of the Petri dish was then homogenized and $1 \mathrm{~mL}$ was removed for ciliate quantification, which was conducted in a Sedgewick-Rafter chamber by observing all fields at 100x magnification. The number of ciliates found in $1 \mathrm{~mL}$ from each host was then multiplied by five to estimate total number of ciliates present. This methodology includes quantification of ectoparasites which may have come loose from the tadpole body surface in the fixation process.

Ciliate identification was based on the uniform system of specific characteristics proposed by Lom (1958), using impregnated specimens (KLEIN 1958). For morphological details see Diss et al. (2009). Analysis of slides prepared for trichodinid quantification was carried out under an Olympus BX51 bright field microscope.

Prevalence, mean intensity, and abundance values were determined according to BusH et al. (1997). Tadpoles were separated into four weight classes using the statistics program SPSS 11.5 for Windows to investigate any relationships between these characteristics and mean trichodinid infestation intensity. The non-parametric Kruskal-Wallis test was used to test significant differences in infestation intensity between these classes. The software used for statistical analysis was BioEstat 5.0 (Ayres et al.
2007). The Discrepancy index "D" (Poulin 1993) was calculated to determine the pattern of ectoparasite distribution in the host population. This index measures the difference between the observed parasite distribution and a hypothetical distribution in which all hosts possess the same number of parasites. This D value can range from zero to one; the closer to one, the greater the degree of aggregation, the closer to zero, the greater the uniformity of distribution (Poulin 1993). The discrepancy index was calculated using Quantitative Parasitology 2.0 (Rozsa et al. 2000). Arithmetic means are followed by standard deviation. Values were considered significant when $\mathrm{p}<0.05$.

The diameters of 30 trichodinids from the same host were determined to check whether infestation intensity influenced average ciliate diameter as a density-dependent effect. In other words, we aimed to ascertain if parasite density affects the size of each individual parasite. Trichodinids from 70 tadpoles were measured, totalling 2100 ciliates. Mean ectoparasite intensity and diameter for each host were submitted to simple linear regression analysis and Pearson's correlation test.

\section{RESULTS}

Examination of the body surface of $80 R$. pombali tadpoles revealed monospecific infestation by $T$. heterodentata (Figs 1-4), and $100 \%$ parasitic prevalence. As all hosts examined were infested, the mean intensity value was equal to the mean abundance, which was 695.14 \pm 335.12 ciliates/tadpole (ranging from 75-1425 ciliates/tadpole). Trichodina heterodentata infrapopulations showed a uniform distribution pattern $(\mathrm{D}=0.286)$ in their host population.

Infestation intensity was positively correlated with host weight: a significant increase in infestation intensity was observed with increased tadpole weight (Tab. I). In other words, heavier tadpoles had a higher parasite load (Fig. 5). The mean T. heterodentata infestation intensity in the four host weight classes are shown in figure 6.

Infestation intensity had no significant influence on mean trichodinid diameter, as demonstrated by the simple linear regression analysis (Fig. 7). No significant correlation ( $\mathrm{p}=$ 0.66 , Pearson's coefficient $=0.053$ ) was observed between infestation intensity and trichodinid diameter, indicating an absence of density-dependent effects on this trait in the ectoparasite infrapopulations studied.

\section{DISCUSSION}

We observed a significant increase in $T$. heterodentata infestation intensity in heavier tadpoles (Figs 5 and 6). This suggests that the degree of trichodinid infestation may be directly correlated with tadpole weight. Data on the relationship between trichodinid infestation intensity and host weight are scarce in the literature. Also, host size is recognised as a factor that influences parasite intensity and abundance. Larger hosts 

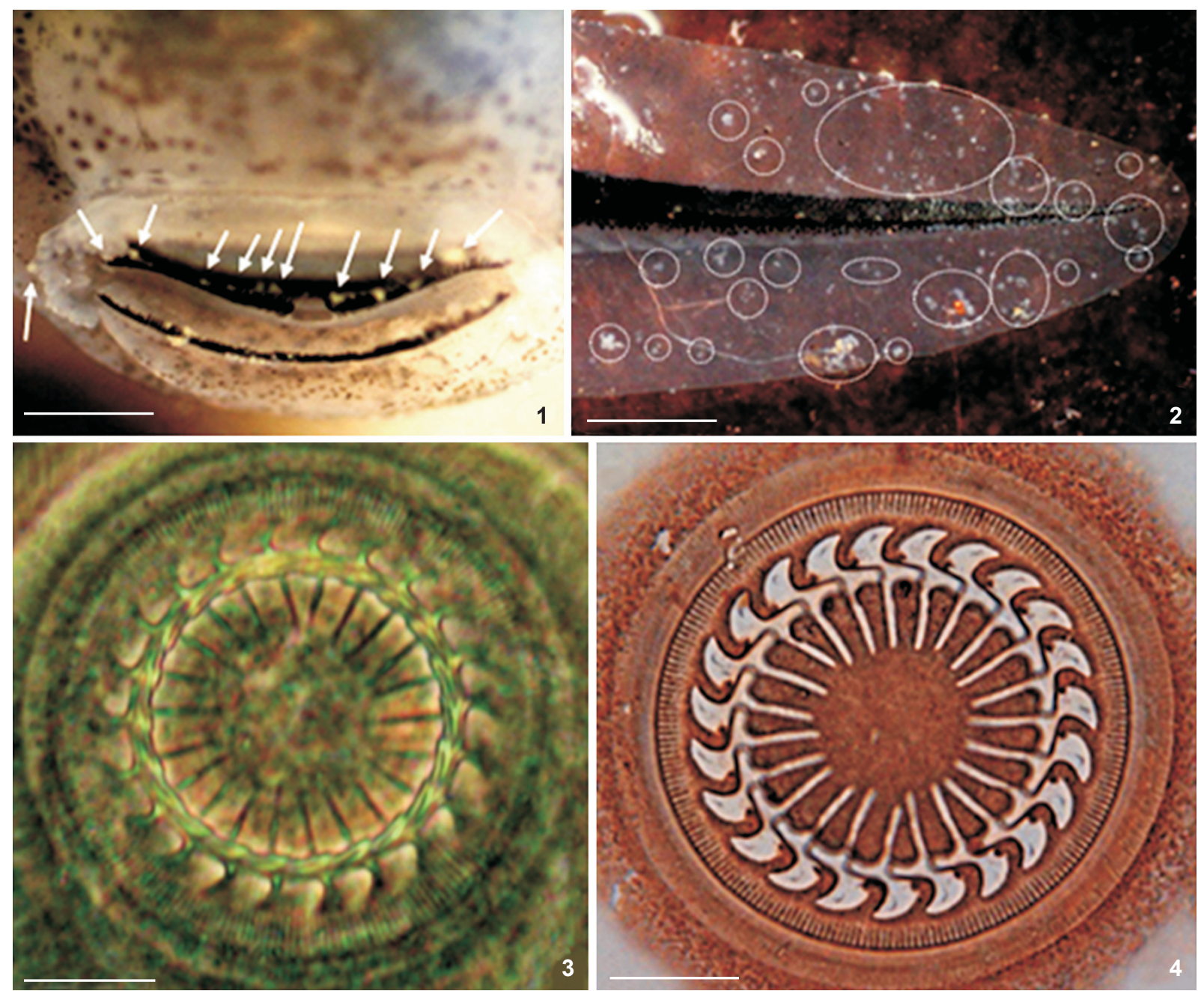

Figs 1-4. Trichodina heterodentata infesting tadpoles of a Brazilian toad Rhinella pombali. (1) Oral region of $R$. pombali infested by $T$. heterodentata, arrows indicates attached parasites. (2) Trichodinids infesting the tadpole tail. Highlighted white spots are the ectoparasites. (3) Trichodina heterodentata from life. (4) Details of the T. heterodentata adhesive disk evidenced by silver-impregnation method (Klein, 1958). Scale bars: $1-2=1 \mathrm{~cm} ; 3-4=20 \mu \mathrm{m}$.

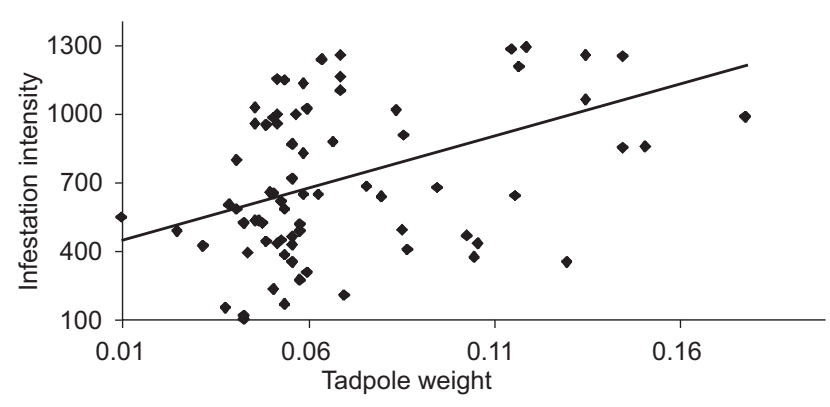

Figure 5. Linear regression analysis between infestation intensity by Trichodina heterodentata and weight of Rhinella pombali tadpoles. Heavier tadpoles show higher infestation intensity. can usually harbour a larger number of parasites (ÖZER 2003). In general, there is an increase in the degree of infection for both ecto- and endoparasites in relation to host growth, possibly as a result of a longer accumulation period or a larger space for the parasite to feed and develop (Rhode 1993). Some authors (ÖZER \& ERDEM 1998, ÖZER 2003) observed a positive correlation between mean trichodinid intensity and fish length. ÖZER (2007), however, did not find significant differences between mean trichodinid intensity in different fish length classes.

Defense mechanisms against ectoparasites in amphibians are innate, adaptive immune response, which are less effective in the larval stage, and can directly influence infestation intensity (Green 2001). This fact was also observed by Kattar (1975). He recorded T. steini on the larvae of Xenopus laevis 


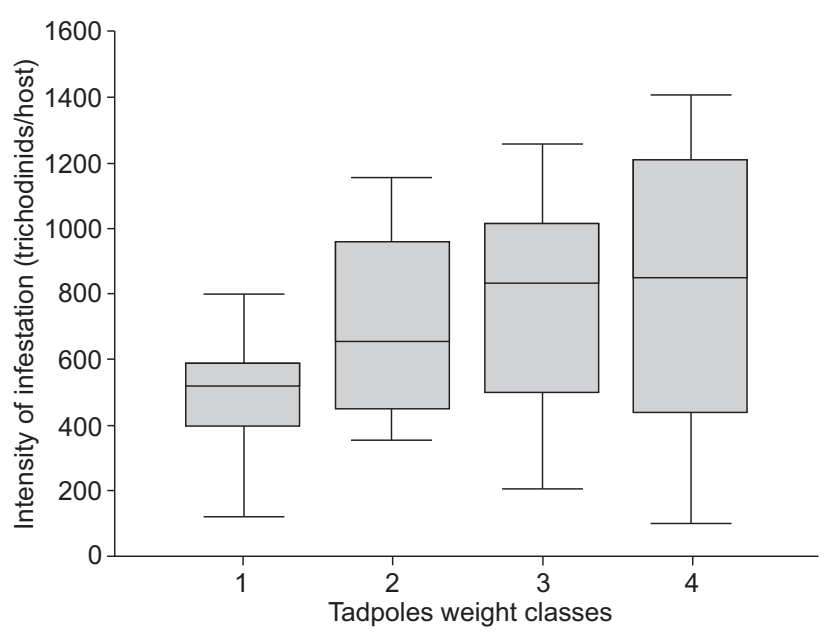

Figure 6. Infestation intensity by Trichodina heterodentata on Rhinella pombali tadpoles weight classes. The boxes represent the distribution of infestation intensity within the classes. Host weight classes $=1: 0.01-0.049 \mathrm{~g} ; 2: 0.05-0.056 \mathrm{~g} ; 3: 0.057-0.086 \mathrm{~g} ; 4$ : 0.087-0.447 g.

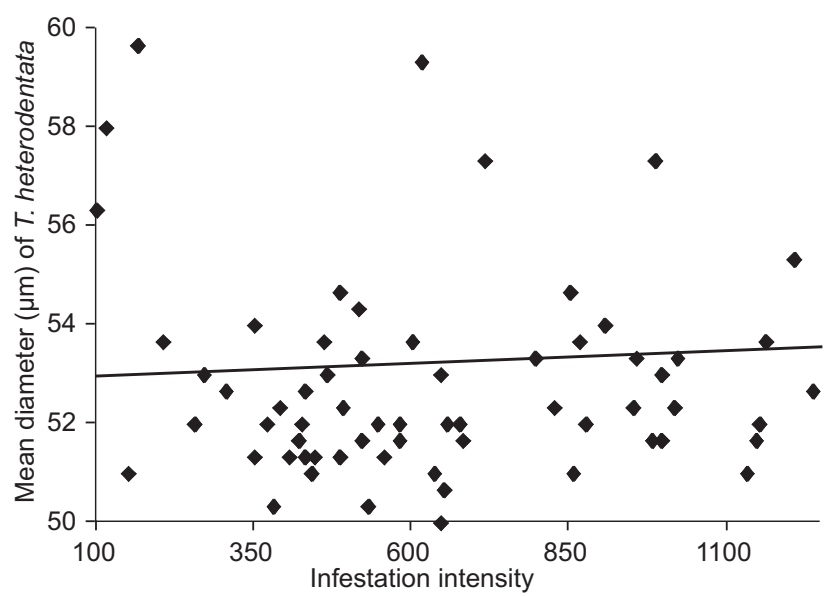

Figure 7. Linear regression analysis between the mean diameter of the Trichodina heterodentata and infestation intensity over 70 Rhinella pombali tadpoles.
(Daudin, 1802), but not on the adults. Those studies indicate that parasite intensity may be related to the developmental stage of the tadpole. However, there is no published study on the possible alterations Trichodina spp. infestations cause on the development of amphibians.

One of the most common characteristics of parasitic populations is the tendency to present an aggregated distribution pattern within the host population (ANDERSON \& GORDON 1982). Contrasting with that trend, the populations of $T$. heterodentata analysed in this study presented a uniform distribution ( $\mathrm{D}=0.286$ ). According to Poulin (1993), the discrepancy index $\mathrm{D}$ indicates that parasite aggregation and mean intensity decrease with increasing prevalence. This hypothesis is supported by our study, in which ectoparasite prevalence and aggregation were shown to be inversely correlated.

The uniform ectoparasite distribution found in this study may be due to host aggregation. According to ANDERson \& GoRDON (1982), a determining factor in parasite distribution patterns is the rate of transmission, which is more intense in aggregated hosts. Rhinella pombali tadpoles can live in isolation, but often gather in circular groups. Such arrangement is more efficient than isolation when it comes to obtaining food (ЕтеRоvick 2000). Aggregation in tadpoles results from a complex interaction of factors such as light intensity, water temperature, food type and distribution, and inter-larval behaviour (BEISWENGER 1975), and can be a mechanism for reducing the risk of predation (SPIELER \& LiNSENMAIR 1998). However, aggregation favours ectoparasite dispersion in the population (Krebs \& Davies 1996) and may be the cause of the high prevalence of parasites and the uniform pattern of parasitic distribution found in this study.

In endoparasitic helminth populations, there is generally an inverse relationship between body size and infestation intensity. In ectoparasite populations, by contrast, this relationship is often positive (Poulin 1999). We did not observe the latter trend in our trichodinid population, and found no significant relationship between mean ectoparasite diameter and infestation intensity, possibly because the regulation of parasite size as a density-dependent effect is common in larger species and when resources are limited (Poulin 1999). Densitydependent effects occur in parasite populations with aggregate distribution, when there is greater competition for food and

Table I. Mean intensity followed by standard deviation of Trichodina heterodentata on Rhinella pombali tadpoles weight classes. Statistical Kruskal-Wallis test (non-parametric ANOVA) was used to determine significant differences between the classes $(p<0.05=$ classes differ statistically).

\begin{tabular}{cccc}
\hline Host weight classes $(\mathrm{g})$ & Mean intensity \pm S.D. & Comparison between classes & Significance \\
\hline & & $1 \times 2$ & $\mathbf{0 . 0 2}$ \\
Classe 1: $0.010-0.049(\mathrm{n}=20)$ & $562.0 \pm 341.2$ & $1 \times 3$ & $\mathbf{0 . 0 3}$ \\
Classe 2: $0.050-0.056(\mathrm{n}=20)$ & $662.2 \pm 300.5$ & $2 \times 3$ & $\mathbf{0 . 0 3}$ \\
Classe 3: $0.057-0.086(\mathrm{n}=21)$ & $785.4 \pm 325.0$ & $3 \times 4$ & 0.12 \\
Classe 4: $0.087-0.447(\mathrm{n}=19)$ & $816.3 \pm 402.2$ & $4 \times 2$ & 0.16 \\
\hline
\end{tabular}


space (Poulin 1999). Density-dependent mechanisms can only act if there is competition for space on the host, or when an immune response against the parasite is in place (BoER 1991, Poulin 2007). As trichodinids are not obligatory parasites, i.e., they can be found feeding and reproducing freely in the water, unattached to a host, these microorganisms may face less competition for space and food.

The high infestation intensities (26-1410 ciliates/tadpole) and prevalence observed in this study may be an evidence of environmental degradation. PALm \& Dobberstein (1999) recommended the use of Trichodina sp. prevalence and parasite density data as a biological indicator for comparing between organically polluted and non-polluted areas. They suggested that such parameters are related to bacterial biomass in the environment. OGuT \& PALM (2005) showed that the prevalence of trichodinids is higher in organically polluted sites, and advocated that this parameter can be used to indicate levels of organic pollution. Trichodinids also have four characteristics of good bioindicators, as proposed by MaCKenzIE (1983): they are easy to remove from their host, easy to identify at the generic level, able to respond quickly to changing environmental conditions, and are non-pathogenic at low intensities. These aspects strongly suggest that the prevalence and intensity of trichodinid infestations might be useful as an individual measure for assessing the biological integrity of aquatic ecosystems.

Most studies on Trichodina discuss the morphology and taxonomy of the included species, and focus on their economic impact on fish farming. Most reports on ectoparasitism by $T$. heterodentata concern fish from different families (Dove \& O'Donoghue 2005, Martins et al. 2010). Trichodina heterodentata was recently documented parasitizing the channel catfish Ictalurus punctatus in Brazil (Rafinesque, 1818) (MarTins et al. 2010). According to VAN As \& BAsson (1992), it is one of the trichodinid species with the widest distribution, and has low specificity, being able to infest a wide range of vertebrate and invertebrate hosts in both marine and freshwater environments (Dove \& O'Donoghue 2005, MarTins et al. 2010). Therefore, quantitative studies of trichodinid parasitism in other host groups, especially endemic species, are also important for conservation.

In summary, this study presented a quantitative analysis of parasitism by $T$. heterodentata, an introduced ectoparasite infesting a toad species endemic to the Brazilian rainforest. Our results show that the ectoparasite has a high prevalence, high infestation intensity, and uniform distribution pattern on the host population. We also found a positive correlation between parasite abundance and host weight. Additionally, there is no significant density-dependent effect on the mean diameter of T. heterodentata.

These results highlight the importance of understanding the quantitative aspects of parasite species commonly found parasitizing fish and other introduced hosts in biodiversity conservation studies.

\section{ACKNOWLEDGMENTS}

We are grateful to Denise de C. Rossa-Feres and Diogo Borges (Unesp) who made the identification of the tadpoles, and to Patrícia Silveira for the logistic support. We are thankful to Guilherme Muricy (Museu Nacional, Universidade Federal do Rio de Janeiro) for suggestions and revision of the manuscript. We would like to thank to Robert Poulin (University of Otago, New Zealand) for providing access to bibliography about ecology of parasites. Also thank to Instituto Brasileiro do Meio Ambiente e dos Recursos Naturais Renováveis (Ibama) for granting license to collect. This study was financially supported by FAPEMIG.

\section{LITERATURE CITED}

Anderson, R.M. \& D.M. Gordon. 1982. Processes influencing the distribution of parasite numbers within host populations with special emphasis on parasite-induced host mortalities. Parasitology 85 (2): 373-98. doi: 10.1017/S0031182000055347.

Ayres, M.; M.J. Ayres; D.L. Ayres \& A.A.S. Santos. 2007. BioEstat 5.0 Aplicações estatísticas nas áreas das ciências bio-médicas. Belém, Sociedade Civil Mamirauá, XXIV+380p.

BALDISSERA, F.A.J. 2008. In: IUCN - Red List Unit (Ed.). IUCN Red list of threatened species, version 2010.4, Rhinella pombali. Available online at: www.iucnredlist.org [Accessed: 15.XII.2010].

Baldissera, F.A.J; U. Caramaschi \& C.F.B. Haddad. 2004. Review of the Bufo crucifer species group, with descriptions of two new related species (Amphibia, Anura, Bufonidae). Arquivos do Museu Nacional 62 (3): 255-282.

BEISWENGER, R.E. 1975. Structure and function in aggregations of tadpoles of the American toad, Bufo americanus. Herpetologica 31 (2): 222-233.

BoER, P.J. 1991. Seeing the trees for the wood: Random walks or bounded fluctuations of population size. Oecologia 86 (4): 484-491. doi: 10.1007/BF00318314.

Bush, A.O.; K.D. Lafferty; J.M. Lotz \& A.W. Shostak. 1997. Parasitology meets ecology on its own terms Margolis et al. revisited. Journal of Parasitology 83 (4): 575-583.

Chen, C.L. 1963. Studies on the ectoparasites trichodinids from freshwater fish, tadpole and crustacean in China. Acta Hydrobiologica Sinica 3 (1): 99-111.

Churcher, T.S.; J.A.N. Filipe \& M.G. Basánez. 2006. Density dependence and control of helminth parasites. Journal of Animal Ecology 75 (6): 1313-1320. doi: 10.1111/j.13652656.2006.01154.

Dezfuli, B.S.; S. Volponi; I. Beltrami \& R. Poulin. 2002. Intra- and interspecific density-dependent effects on growth in helminth parasites of the cormorant, Phalacrocorax carbo sinensis. Parasitology 124 (5): 537-544. doi: 10.1017/ S0031182002001555.

Dias, R.J.P.; N.M. Fernandes; B. Sartini; I.D. Silva-Neto \& M.T. D'Agosto. 2009. Occurrence of Trichodina heterodentata 
(Ciliophora: Trichodinidae) infesting tadpoles of Rhinella pombali (Anura: Bufonidae) in the Neotropical area. Parasitology International 58 (4): 471-474. doi:10.1016/ j.parint.2009.06.009.

DilLeR, W.F. 1928. Binary fission and endomixis in the Trichodina from tadpoles (Protozoa: Ciliata). Journal of Morphology 46 (2): 521-561. doi: 10.1002/jmor.1050460206.

Dove, A.D.M. \& P.J. O’Donoghue. 2005. Trichodinids (Ciliophora: Trichodinidae) from native and exotic Australian freshwater fishes. Acta Protozoologica 44 (1): 51-60.

Eterovick, P.C. 2000. Effects of aggregation on feeding of Bufo crucifer tadpoles (Anura: Bufonidae). Copeia 1 (1): 210-215. doi: 10.1643/0045-8511(2000)2000.

GosNER, K.L. 1960. A simplified table for staging anuran embryos and larvae with notes on identification. Herpetologica 16 (3): 183-190.

Green, D.E. 2001. Pathology of amphibian, p. 401-485. In: K.M. Wright \& B.R. Whitaker (Eds). Amphibian Medicine and Captive Husbandry. Malabar, Krieger Publishing Company, XXV+499p.

Kattar, M.R. 1975. Sobre Trichodina steini Claparède \& Lachmann (Protozoa, Urceolariidae) encontrada em girino de Bufo ictericus do Brasil. Revista Brasileira de Biologia 35 (2): 253-258.

KLeIN, B.M. 1958. The dry silver method and its proper use. Journal of Protozoology 5 (2): 99-103. doi: 10.1111/j.15507408.1958.tb02535.x.

Krebs, J.R. \& N.B. Davies. 1996. Introdução à Ecologia Comportamental. São Paulo, Atheneu, XV+420p.

LoM, J. 1958. A contribution to the systematics and morphology of endoparasitic trichodinids from amphibians with proposal of uniform specific characteristics. Journal of Protozoology 5 (4): 251-263. doi: 10.1111/j.15507408.1958.tb02563.x.

Lom, J. 1995. Trichodinidae and other ciliates (Phylum Ciliophora), p. 229-262. In: P.T.K. Woo (Ed.). Fish Diseases and Disorders: Protozoan and Metazoan Infections. Wallingford, CAB International, $\mathrm{X}+808 \mathrm{p}$.

MACKENZIE, K. 1983. Parasites as biological tags in fish populations studies. Advances in Applied Biology 7 (1): 251-331.

Martins, M.L.; N. Marchiori; G. Nunes \& M.P. Rodrigues. 2010. First record of Trichodina heterodentata (Ciliophora: Trichodinidae) from channel catfish, Ictalurus punctatus cultivated in Brazil. Brazilian Journal of Biology 70 (3): 637-644.

Myers, N.; R.A. Mittermeier; C.G. Mittermeier; G.A. DA Fonseca \& J. Kenty. 2000. Biodiversity hotspots for conservation priorities. Nature 403 (1): 853-858. doi: 10.1038/35002501.

Nieto, N.C.; M.A. Camann; J.E. Foley \& J.O. Reiss. 2007. Disease associated with integumentary and cloacal parasites in tadpoles of northern red-legged frog Rana aurora aurora. Diseases of Aquatic Organisms 78 (1): 61-71. doi: 10.3354/dao01851

Ogut, H. \& H.W. Palm. 2005. Seasonal dynamics of Trichodina spp. on whiting (Merlangius merlangus) in relation to organic pollution on the eastern Black Sea coast of Turkey. Parasitology Research 96 (3): 149-153. doi: 10.1007/s00436-005-1346-2.

Özer, A. 2003. Trichodina domerguei Wallengren, 1897 (Ciliophora: Peritrichia) infestations on the Round Goby, Neogobius melanostomus Pallas, 1811 in relation to seasonality and host factors. Comparative Parasitology 70 (2): 132-135. doi: 10.1654/4073.

Özer, A. 2007. Trichodina modesta Lom, 1970 (Ciliophora: Peritrichia) infestations of an endemic Toothcarp Aphanius danfordii Boulenger, 1890 (Pisces: Cyprinodontidae) in Sinop, Turkey. Journal of Natural History 41 (41-44): 2543-2549. doi: 10.1080/00222930701739724.

Özer, A. \& O. Erdem. 1998. Ectoparasitic protozoa fauna of the common carp (Cyprinus carpio L., 1758) caught in the Sinop region of Turkey. Journal of Natural History 32 (3): 441454. doi: 10.1080/00222939800770231.

Palm, H.W. \& R.C. Dobberstain. 1999. Occurrence of trichodinid ciliates (Peritrichia: Urceolariidae) in the Kiel Fjord, Baltic Sea, and its possible use as a biological indicator. Parasitology Research 85 (8-9): 726-732. doi: 10.1007/s004360050622.

PARRIS, M.J. \& D.R. BAUD. 2004. Interactive effects of a heavy metal and chytridiomycosis on gray treefrog larvae (Hyla chrysoscelis). Copeia 2 (2): 344-350. doi: 10.1643/CE-03-116R1.

Poynton, S.L. \& B.R. WhitaKer. 2001. Protozoa and metazoan infecting amphibians, p. 193-221. In: K.M. WRIGHT \& B.R. WHITAKER (Eds). Amphibian medicine and captive husbandry. Malabar, Krieger Publishing Company, XXV+499p.

Poulin, R. 1993. The disparity between observed and uniform distributions: a new look at parasite aggregation. International Journal for Parasitology 23 (7): 937-944. doi: 10.1016/00207519(93)90060-C.

Poulin, R. 1999. Body size vs abundance among parasite species: positive relationships? Ecography 22 (3): 246-250. doi: 10.1111/j.1600-0587.1999.tb00499.x.

Poulin, R. 2007. Evolutionary ecology of parasites. Princeton, Princeton University Press, $2^{\text {nd }}$ ed., XI+348p.

ROHDE, K. 1993. Ecology of marine parasites, an introduction to marine parasitology. Wallingford, $\mathrm{CAB}$ International, $2^{\text {nd }}$ ed., XIV+298p.

Rozsa, L.; J. Reiczigel \& G. Majoros. 2000. Quantifying parasites in samples of hosts. Journal of Parasitology 86 (2): 228232. doi: 10.1645/0022-3395(2000)086.

Silveira, A.L.; R.O.L. Salles \& R.C. Pontes. 2009. Primeiro Registro de Rhinella pombali e novos registros de $R$. crucifer e $R$. ornata no Estado do Rio de Janeiro, Brasil (Amphibia, Anura, Bufonidae). Biotemas 22 (4): 231-235.

SPieler, M. \& K.E. LinsenMaIr. 1998. Aggregation behaviour of Bufo maculatus tadpoles as an antipredator mecanism. Ethology 105 (8): 665-686. doi: 10.1046/j.1439-0310.1999.00446.x.

Stuart, S.N.; J.S. Chanson; N.A. Cox; B.E. Young; A.S.L. Rodrigues; D.L. Fischman \& R.W. Waller. 2004. Status and trends of amphibian declines and extinctions worldwide. Science 306 (5702): 1783-1786. doi: 10.1126/science.1103538. 
Tomava, C. \& V. Golemansky. 2001. Protozoan parasites of amphibians (Amphibia: Anura) and reptiles (Reptilia: Squamata) from Bulgaria. Acta Zoologica Bulgarica 53 (1): 41-46.

VAN As, J.G. \& L. BAsson. 1992. Trichodinid ectoparasites (Ciliophora: Peritrichida) of freshwater fishes of the Zambesi
River System, with a reappraisal of host specificity. Systematic Parasitology 22 (2): 81-109. doi: 10.1007/BF00009603.

Zanolo, R. \& M.H. Yamamura. 2006. Parasitas em tilápias do Nilo criadas em sistema de tanque-rede. Semina: Ciências Agrárias 27 (2): 281-288.

Submitted: 12.VII.2011; Accepted: 19.IX.2011.

Editorial responsibility: Marcus V. Domingues 